\title{
Base-temperature, plastochron and chia (Salvia hispanica L. - Lamiaceae) yield for different sowing times
}

\author{
Jana Koefender $^{*}$ (D), Juliane Nicolodi Camera ${ }^{1}$, João Fernando Zamberlan ${ }^{1}$, Willian Felipe Genz ${ }^{1}$, André Schoffel ${ }^{2}$
}

$10.1590 / 0034-737 X 202168020010$

\begin{abstract}
Chia is a plant whose seeds are used in cooking and is a natural source of omega- 3 fatty acids, fiber and protein, as well as other important nutritional components such as antioxidants. The objective of this work was to estimate the base temperature, plastochron and chia seed yield for different sowing times in Cruz Alta, Rio Grande do Sul, Brazil. The experimental design was completely randomized and the treatments consisted of different sowing times (September, October and November). For the determination of the base temperature for node emission in the main stem of the plants, the method of least mean square error of linear regression between the number of nodes and the accumulated thermal sum was used. Regarding estimation of the plastochron at each sowing time, a simple linear regression was obtained between the number of nodes in the main stem and the accumulated thermal sum. Seed yield was measured at harvest. Sowing in times with air temperature below $19^{\circ} \mathrm{C}$ should be avoided so that the development of plants is not impaired. Plastochron ranges from $28.01^{\circ} \mathrm{C}$ to $32.26^{\circ} \mathrm{C}$ day for successive node emission in the main stem of chia plants and September sowing promotes higher seed yield.
\end{abstract}

Keywords: lower base temperature; number of nodes; plant development.

\section{INTRODUCTION}

Chia (Salvia hispanica L. - Lamiaceae) is an annual herbaceous plant native to southern Mexico and northern Guatemala (Álvarez-Chávez et al., 2008). It seeds are considered an important source of fiber, protein and antioxidants. In South America, Argentina is one of the pioneer countries when it comes to the development of research on its cultivation because the plant is considered an alternative for diversification and stability of the northwestern Argentine farms, which reached a yields of $1,602 \mathrm{~kg} \mathrm{ha}^{-1}$ and $38.6 \%$ contents of oil in the seeds have been recorded (Coates \& Ayerza, 1996).

The oil is composed of linoleic acid and omega- 3 fatty acid (Rosamond, 2002), which are associated with benefits to the human health. In addition, Vázquez-Ovando et al. (2009) found high antioxidant activity, which confirms the presence of polyphenols. Furthermore, the observed physicochemical properties indicate that the fraction rich in fiber may be an ingredient for the human diet, in items a such as powders, cereal bars, breads, cookies, beverages, jams, emulsions, among others (Capitani et al., 2012). Another important feature is the absence of gluten, which means that chia flour can replace wheat flour in various foods designed for people intolerant to this compound protein (Bueno et al., 2010).

Commercial crops of chia are commonly reported in Oceania, Central America, and South America (OronaTamayo et al., 2017). In northwestern Rio Grande do Sul, some farmers have been cultivating chia in the last years for seed production. However, the scarcity of technical information on cultivation techniques and requirements and the limited market has been hindering the expansion of the crop (Migliavacca et al., 2014).

Submitted on March 24th, 2020 and accepted on November $2^{\text {nd }}, 2020$.

'Universidade de Cruz Alta, Curso de Agronomia/Mestrado Profissional em Desenvolvimento Rural, Cruz Alta, Rio Grande do Sul, Brazil. jkoefender@unicruz.edu.br; jcamera@unicruz.edu.br; jfzamberlan@unicruzedu.br; williangenz123@unicruz.edu.br

${ }^{2}$ Universidade Federal de Santa Maria, Santa Maria, Rio Grande do Sul, Brazil. andre-schoffel@hotmail.com

*Corresponding author: jkoefender@unicruz.edu.br 
In order to increase productivity in agricultural crops, it is necessary to know the temperature ranges that contribute to the plant development, as well as the definition of the appropriate sowing time. The appearance of nodes in the main stem is an excellent measure for understanding the crop development cycle and the rate of appearance of nodes in the main stem is an efficient measure to quantify the time and physiological development of the plant (Streck et al., 2003).

Temperature affects plant growth and one way used to describe this interaction is through degree-days $\left({ }^{\circ} \mathrm{C}\right.$ day), which has a direct relationship with the accumulation of daily heat units or daily thermal sum. Thermal sum has been used to represent the effect of air temperature on plant growth because it is more biologically effective. In this context, the base temperature is that below which plant development is zero or insignificant. For the accurate estimation of plant development, the estimation of the base temperature is crucial, since it is inserted in the equation that determines the daily thermal sum (Lago et $a l ., 2009)$. The method of the minimum mean square error of linear regression between the number of leaves / nodes and the accumulated thermal sum was used to determine the base temperature in corn (Streck et al., 2009), watermelon (Lucas et al., 2012) and gladiolus (Schwab et al., 2017), proving to be adequate. Through the method, the value of the base temperature is the one that presents the smallest mean square error and, consequently, indicates a high degree of association between the number of nodes emitted and the accumulated thermal sum for the emission of successive nodes in the main stem.

Plastochron represents the time needed for successive nodes to appear on a stem. It is a simple method that contributes to the prediction of the occurrence of developmental stages in cultivated plants, considering as a time measure the number of days after sowing (Gilmore Jr \& Rogers, 1958) or the thermal sum. Due to the importance of base temperature estimation and improvement of management techniques for chia cultivation, the objective of this study was to estimate the base temperature, plastochron and chia seed yield in three sowing times.

\section{MATERIAL AND METHODS}

The experiment was conducted at the University of Cruz Alta (Unicruz) in 2012/2013, located in Cruz Alta-RS, Brazil, latitude $28^{\circ} 38^{\prime} 19^{\prime \prime} \mathrm{S}$, longitude 53 $36^{\prime} 23^{\prime \prime} \mathrm{W}$ and altitude of $452 \mathrm{~m}$. The area is in the northwest region of Rio Grande do Sul and the climate of the region is subtropical (Kuinchtner \& Buriol, 2001). The average air temperature is $18.7^{\circ} \mathrm{C}$, with an average minimum temperature of $9.2^{\circ} \mathrm{C}$ in July and a maximum average of $30.8^{\circ} \mathrm{C}$ in January (Pes et al., 2011). The average annual rainfall is $1721 \mathrm{~mm}$, evenly distributed throughout the year. The soil is classified as Typical Dystrophic Red Latosol, clay texture (Empresa Brasileira de Pesquisa Agropecuária, 2013).

Soil analysis in the $0-20 \mathrm{~cm}$ layer showed the following chemical characteristics: $\mathrm{pH}$ in water 5.2; O.M. 2.4\%; P 1.4 mg dm³ K 123 mg dm 3 ; exchangeable Al 0.9 cmolc dm $^{3}$; Ca 2.9 cmolc dm$^{3} ; \mathrm{Mg} 1.3 \mathrm{cmolc} \mathrm{dm}^{3} ; \mathrm{H}+\mathrm{Al} 6.9 \mathrm{cmolc} \mathrm{dm}^{3}$ and base saturation $40 \%$.

The experimental design was completely randomized, with three treatments that consisted of sowing times (28 of September, 31 of October and 28 of November) and seven replications. On each sowing times, tillage was carried out with plowing followed by harrowing and liming of $2.5 \mathrm{t} \mathrm{ha}^{-1}$. The plots were 10 meters long, four rows spaced at $0.80 \mathrm{~m}$ and the sowing density was $6 \mathrm{~kg} \mathrm{ha}^{-1}$, and manually accomplished. The seeds used were acquired from a local producer from the previous crop.

Fifteen plants per plot were marked in the field with colored wires for weekly counting of the nodes emitted in the main stem after the first node appeared until the beginning of flowering for the estimation of base temperature. The leaves were considered visible when the edges were no longer touching each other.

The method used to determine the daily thermal sum was: $\mathrm{TSd}=\mathrm{T}_{\text {average }}-\mathrm{Tb}$ where: $\mathrm{T}_{\text {average }}$ is the average daily temperature and $\mathrm{Tb}$ is the base temperature (Arnold, 1960). The accumulated thermal sum (TSa) was calculated by summing up the values of TSd. Temperature data were collected from the automatic weather station Davis Vantage Pro 2 Plus (Davis Instruments, Hayward, CA, USA) located approximately $200 \mathrm{~m}$ from the experimental area.

For the determination of the base temperature for node emission in the main stem of chia plants, the method of the minimum mean square error (MSE) of linear regression between the number of nodes and the accumulated thermal sum was used. Thus, the values of base temperature ranging from zero to $21^{\circ} \mathrm{C}$ with an increment of $1{ }^{\circ} \mathrm{C}$ and the base temperature value was the one with the lowest MSE were used (Sinclair et al., 2004).

Plastochron was estimated at each sowing time by obtaining a simple linear regression between the number of nodes in the main stem and the accumulated thermal sum, using as the base temperature the one estimated in this study. Plastochron was estimated by the inverse of the angular coefficient of linear regression between node number and accumulated thermal sum (Streck et al., 2005).

During the development of the crop, the following was evaluated: the duration of the sowing phases until emergence, emergence until flowering, flowering at the beginning of seed filling and seed filling until harvest, considering that the phase was reached when $50 \%$ of the 
plants showed emergence, flowering, beginning of seed filling and full ripening for harvest, respectively. At harvest, seed yield $\left(\mathrm{kg} \mathrm{ha}^{-1}\right)$ was measured.

Assumptions of mathematical model were verified before analysis of variance by homogeneity of treatment variances and normality of errors by Bartlett's and Shapiro-Wilk's tests $(\mathrm{p}<0.05)$, respectively. If the assumptions were not met, a Box-Cox procedure was used to verify an appropriate transformation for data using Action software (Equipe Estatcamp, 2014). Productivity data were subjected to analysis of variance and means were cluster by Scott-Knott test at $5 \%$ probability of error $(\mathrm{p}<0.05)$.

\section{RESULTS AND DISCUSSION}

It was observed for the three sowing times that the minimum and maximum average temperatures were 15.4 and $27^{\circ} \mathrm{C}$, respectively (Figure 1a). In absolute values, the minimum and maximum temperatures were $2.4^{\circ} \mathrm{C}$ and $35.9^{\circ} \mathrm{C}$ and the average temperature was $21.6^{\circ} \mathrm{C}$. Until the beginning of flowering, the minimum and maximum absolute temperatures were 8.4 and $35.9^{\circ} \mathrm{C}$, which shows that the crop was subjected to low temperatures over the vegetative development period, which is important for the estimation of the base temperature.

The September sowing time showed the shortest length of the sowing phase until emergence (SOW-EME), with accumulated thermal sum of $5.6^{\circ} \mathrm{C}$ day, while the sowing times of October and November required thermal accumulation of 79.5 and $40.8{ }^{\circ} \mathrm{C}$ day to reach the emergency (Figure 1b). This result demonstrated that the temperature conditions in the early sowing provided a faster emergence compared to the other dates.

The phase from emergence to flowering (EME-FLO) that corresponds to the vegetative period and the elaboration of the reproductive performance of the plant decreased as the sowing time was delayed. Regarding the dates of September, October and November, it was observed that the accumulated thermal sum to complete this phase was $626.7 ; 497.1$ and $424.7^{\circ} \mathrm{C}$ day (Figure 1b). It

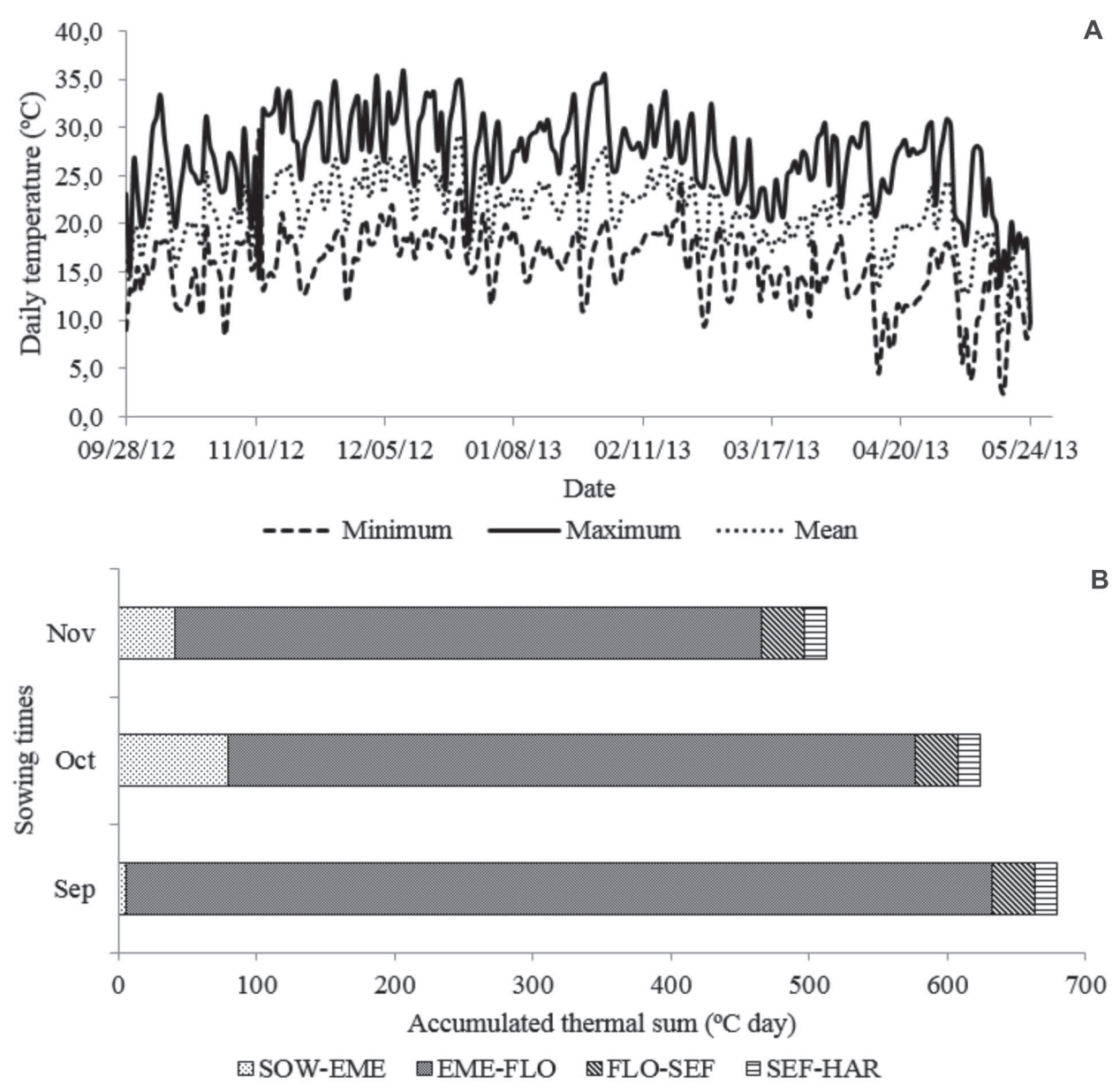

Figure 1: Daily minimum, average and maximum temperatures of chia crop growing for three sowing times (a) and phases of the growth cycle of chia grown for the three sowing times in Cruz Alta - RS (b).

*SOW-EME (sowing to emergence); EME-FLO (emergence to flowering); FLO-SEF (Flowering to seed filling); SEF-HAR (Seed filling to harvest). 
could be inferred from this result that the delay of the sowing time had an influence on the vegetative phase, with a consequent reduction of growth period and development of the crop. Goergen et al. (2019) found that early sowing times, which started in September in Rio Grande do Sul, Brazil, reflect higher dry mass of the aerial part, height and leaf area index. According to Baginsky et al. (2016), the flowering of chia cultivated in Chile occurred with thermal accumulation of 600 to $700{ }^{\circ} \mathrm{C}$ day, which corroborates with the observed in September sowing.

On the other hand, from flowering to the beginning of seed filling (FLO-SEF) and from seed filling to harvest (SEF-HAR), no variation was observed in the accumulated thermal sum in the three sowing times (Figure 1b). This result was due to the fact that the beginning of flowering and seed filling occurred simultaneously in the three sowing times, clearly indicating that the influence of sowing time is mainly on the vegetative phase. On calendar days, the total cycle was $231 ; 185$, and 171 days for the September, October, and November sowing times, respectively. Migliavacca et al. (2014) recommends that the most suitable chia sowing time is from October to November.

For all sowing times, the 66 linear equations between the number of nodes and the accumulated thermal sum for the estimation of the base temperature with initial temperature from $0{ }^{\circ} \mathrm{C}$ to the temperature of $21^{\circ} \mathrm{C}$ presented coefficient of determination greater than 0.956 and mean square error less than 0.582 (Figure 2). It can be verified that the base temperature for chia crop ranged from 19 to $20^{\circ} \mathrm{C}$, where the value of $19^{\circ} \mathrm{C}$ was observed for the sowing time of October where the smallest mean square error was 0.331. For the other dates, the base temperature was $20^{\circ} \mathrm{C}$, with the smallest mean squares of error of 0.321 and 0.332 for the dates of September and November, respectively. Due to the low variation in values for base temperature between dates, it was assumed that the base temperature for the crop was the lowest temperature observed for the emission of successive nodes in the main stem of the plants, that is, $19^{\circ} \mathrm{C}$.

For this temperature, the coefficient of determination was higher than 0.975 in the three sowing times, which indicated the high association between the number of nodes and the accumulated thermal sum. Similar to that verified by Martins, Silva \& Streck (2007) in study to estimate base temperature for eucalyptus species. For this reason, it can be concluded that eucalyptus development is influenced by large-scale air temperature and the relationship of leaf emission (development) and temperature is linear.

The estimated base temperature of $19^{\circ} \mathrm{C}$ was used to obtain the daily thermal sum and subsequent plastochron estimation. For the three sowing times, the coefficient of determination, wich indicates the relationship between the number of nodes in the main stem and the accumulated thermal sum was greater than 0.9727 demostrating that temperature had a predominant effect on the emission of nodes and on the vegetative development of chia crop. Therefore, temperature is the main environmental effect that determinates the appearance of nodes in the main stem of chia crop. According to Streck et al. (2005), the linear regression method is suitable for estimating the emission of leaves or nodes in main stems of agricultural crops.

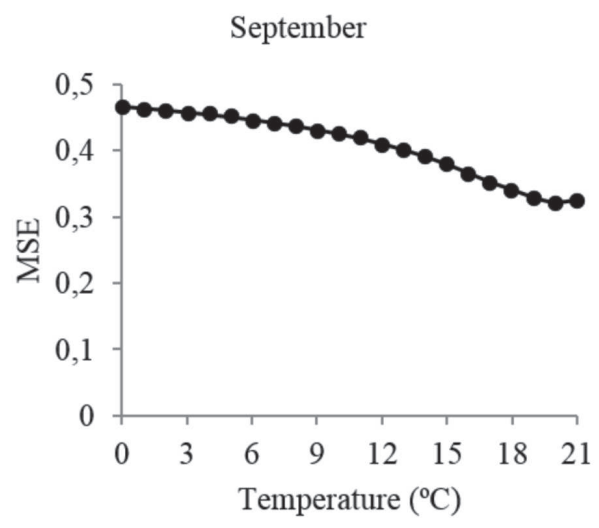

A
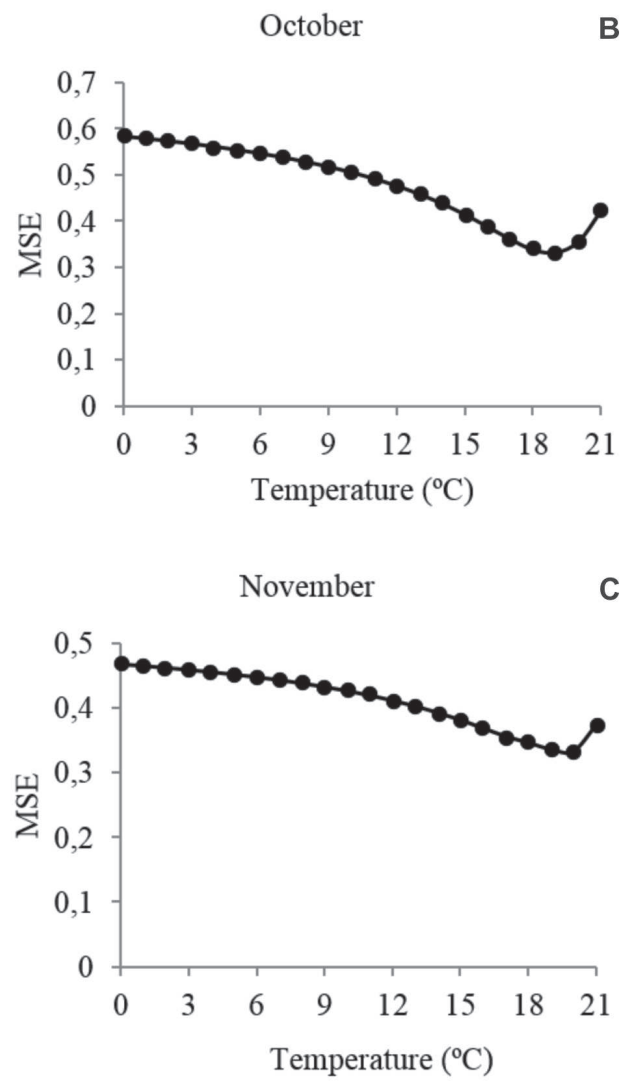

Figure 2: Mean square error (MSE) of the linear regression between the number of nodes on the main stem and the accumulated thermal sum in base-temperature ranging from 0 to $21{ }^{\circ} \mathrm{C}$ for three sowing times (september (a), october (b) and november (c)) of chia in Cruz Alta - RS. 
The values for plastochron ranged from $28.01{ }^{\circ} \mathrm{C}$ to $32.26^{\circ} \mathrm{C}$ day and these results indicate that for the emission of a node in the main stem in the three sowing times there was variation of thermal accumulation of $4.25^{\circ} \mathrm{C}$ day. The higher demand for thermal accumulation in the October sowing time was due to the longer period from sowing phase to emergence. The environmental conditions, especially rainfall after sowing, negatively influenced the emergence and initial development of the crop and, consequently, it caused a higher demand for heat units for the emission of new nodes in the main stem. Nevertheless, it can be seen that the highest accumulated thermal sum demand for emission of nodes did not influence important later phases, such as the beginning of flowering and grain filling. Variations in plastochron values were also observed by Toebe et al. (2010) on crambe (Crambe abyssinica) crop grown at different sowing times.

Seed yield was higher in the September sowing time and differed significantly from October and November (Figure 3). In September, the average yield was $755.35 \mathrm{~kg}$ $\mathrm{ha}^{-1}$ and in October and November sowing, it was 333.32 and $223.35 \mathrm{~kg} \mathrm{ha}^{-1}$, respectively. This result may be related to the greater vegetative period observed in the sowing time of September that culminated in the largest photosynthetic apparatus and, consequently, the highest production of photoassimilates destined for reproductive drains. This result differs from that observed by Win et al. (2018) in a study conducted in China. The authors observed that when the chia crop was exposed to sowing conditions in which the cycle was longer (273 days), the yield was $578 \mathrm{~kg} \mathrm{ha}^{-1}$, while at the sowing, in which the cycle was 218 days, the yield was $852 \mathrm{~kg} \mathrm{ha}^{-1}$. According to the authors, because it is a short-day plant, it is important to avoid sowing times that make the cycle very long and with excessive vegetative growth, which hindered the expression of productivity in the cultivation condition.

It was evidenced that the delay of sowing date drastically reduced the yield of chia seeds, but for the three sowing times, yield was within the limits observed by Grimes et al. (2018), who authors obtained productivity ranging from 100 to $1290 \mathrm{~kg} \mathrm{ha}^{-1}$, this corroborates the statement that chia cultivation is strongly influenced by environmental and management conditions, such as the choice of location and sowing time. In a project conducted in Argentina during three sowing times from January 11 to February 10, Busilacchi et al. (2013) observed a reduction in the average flower spike weight with the delay of the sowing time.

In climatic conditions similar to this research, Goergen et al. (2018) in a study conducted in Santa Maria, Rio Grande do Sul, Brazil, found that chia can be sown from September to February with the production of seeds of high physiological quality. According to Baginsky et al. (2016), the cultivation site was determinant for the expression of the productive potential, where the location in desert conditions in Valle de Azapa and Canchones, Chile, allowed productivity greater than $2900 \mathrm{~kg} \mathrm{ha}^{-1}$ in a place at a higher latitude and lower temperature, yield was less than $129 \mathrm{~kg} \mathrm{ha}^{-1}$. In Bangladesh, Karim et al. (2016) also found variation in yield at different sowing times, when sowing in November enabled the best results, with yield of $1033 \mathrm{~kg} \mathrm{ha}^{-1}$.

The edaphic and climatic conditions in Brazil are favorable for chia cultivation, mainly in relation to temperature, altitude and precipitation. Nevertheless, sowing during the adequate period is important for the

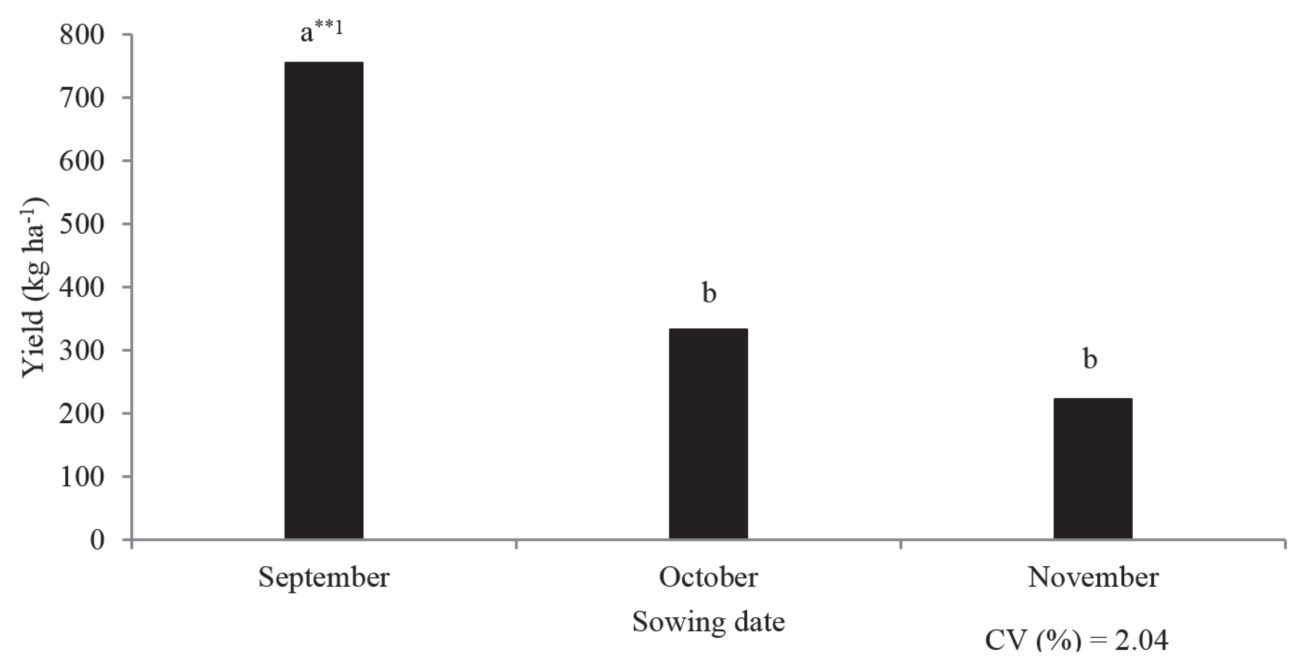

Figure 3: Chia seed yield in sowing times (September, October and November) in Cruz Alta-RS, Brazil.

**Means not followed by the same letter differ from each other by the test of Scott-Knott at $5 \%$ probability.

${ }^{1}$ Transformed data by Box-Cox method. 
success of cultivation. Early or excessively late sowing may be subject to excessive cold or frost, which is a limiting factor for cultivation mainly in the southern region of the country (Migliavacca et al. 2014).

\section{CONCLUSIONS}

Sowing in times with air temperature below $19{ }^{\circ} \mathrm{C}$ should be avoided so that the development of plants is not impaired. Plastochron ranges from $28.01^{\circ} \mathrm{C}$ to 32.26 ${ }^{\circ} \mathrm{C}$ day for successive node emission in the main stem of chia plants and September sowing promotes higher seed yield.

\section{ACKNOWLEDGEMENT, FINANCIAL SUPPORT AND FULL DISCLOSURE}

The authors are grateful to Universidade de Cruz Alta (Unicruz) for funding the research. The authors declare no conflict of interest in the current study.

\section{REFERENCES}

Álvarez-Chávez LM, Valdivia-Lopez MA, Aburto-Juárez ML \& Tecante A (2008) Chemical characterization of the lipid fraction of mexican chia seed (Salvia hispanica L.). International Journal of Food Properties, 11:687-697.

Baginsky C, Arenas J, Escobar H, Garrido M, Valero N, Tello D, Pizarro L, Valenzuela A, Morales L \& Silva H (2016) Growth and yield of chia (Salvia hispanica L.) in the Mediterranean and desert climates of Chile. Chilean Journal of Agricultural Research, 76:255-264.

Busilacchi H, Quiroga M, Bueno M, Di Sapio O, Flores V \& Severin C (2013) Evaluation of Salvia hispanica L. cultivated in the south of Santa Fe (Argentina). Cultivos Tropicales, 34:55-59.

Bueno M, Di Sapio O, Barolo M, Busilacchi H, Quiroga M \& Severin C (2010) Análisis de la calidad de los frutos de Salvia hispanica L. (Lamiaceae) comercializados en la ciudad de Rosario (Santa Fe, Argentina). Boletín Latinoamericano y del Caribe de Plantas Medicinales y Aromáticas, 9:221-227.

Capitani MB, Spotorno V, Nolasco SM \& Tomás M (2012) Physicochemical and functional characterization of by-products from chia (Salvia hispanica L.) seeds of Argentina. Food Science and Technology, 45:94-102.

Coates W \& Ayerza R (1996) Production potential of chia in northwestern Argentina. Industrial Crops and Products, 5:229233.

Empresa Brasileira de Pesquisa Agropecuária (2013) Sistema Brasileiro de Classificação de Solo. $3^{\text {rd }}$ ed. Brasília, Embrapa Informação Tecnológica. 353p.

Equipe Estatcamp (2014) Software Action. Estatcamp Consultoria em estatística e qualidade, São Carlos - SP, Brasil. Available at: http://www.portalaction.com.br/. Accessed on: March $20^{\text {th }}, 2020$.

Gilmore Jr EC \& Rogers JS (1958) Heat units as a method of measuring maturity in corn. Agronomy Journal, 50:611-615.

Goergen PCH, Lago I, Durigon A, Roth GFM, Scheffel LG \& Slim T (2019) Performance of Chia on Different Sowing Dates: Characteristics of Growth Rate, Leaf Area Index, Shoot Dry Matter Partitioning and Grain Yield. Journal of Agricultural Science, 11:252-263
Goergen PCH, Nunes UR, Stefanello R, Lago I, Nunes AR \& Durigon A (2018) Yield and Physical and Physiological Quality of Salvia hispanica L. Seeds Grown at Different Sowing Dates. Journal of Agricultural Science, 10:182-191.

Grimes SJ, Phillips TD, Hahn V, Capezzone F \& Graeff-Hönninger S (2018) Growth, Yield Performance and Quality Parameters of Three Early Flowering Chia (Salvia hispanica L.) Genotypes Cultivated in Southwestern Germany. Agriculture, 8:1-20.

Karim MD, Ashrafuzzaman MD \& Hossain A (2016) Effect of planting time on the growth and yield of chia (Salvia hispanica L.). Asian Journal of Medical and Biological Research, 1:502507.

Kuinchtner A \& Buriol GA (2001) Clima do Estado do Rio Grande do Sul segundo a classificação climática de Köppen e Thornthwaite. Disciplinarum Scientia, 2:171-182.

Lago I, Streck NA, Carvalho MP, Fagundes LK, Paula GM \& Lopes SJ (2009) Estimativa da temperatura base do subperíodo emergência-diferenciação da panícula em arroz cultivado e arroz vermelho. Revista Ceres, 56:288-295.

Lucas DDP, Streck NA, Bortoluzzi MP, Trentin R \& Maldaner IC (2012) Temperatura base para emissão de nós e plastocrono de plantas de melancia. Revista Ciência Agronômica, 43:288-292.

Martins FB, Silva JC \& Streck NA (2007) Estimativa da temperatura-base para emissão de folhas e do filocrono em duas espécies de eucalipto na fase de muda. Revista Árvore, 31:373-381.

Migliavacca RA, Silva TRB, Vasconcelos ALS, Mourão Filho W \& Baptistella JLC (2014) O Cultivo da Chia no Brasil: Futuro e perspectivas. Journal of Agronomic Sciences, 3:161-179.

Orona-Tamayo D, Valverde ME \& Paredes-Lopez O (2017) Chia - The New Golden Seed for the 21st Century: Nutraceutical Properties and Technological Uses. In: Nadathur S, Wanasundara JPD, Scanlin L (Ed.) Sustainable Protein Sources. San Diego, Academic Press. p. 265-281.

Pes LZ, Amado TJC, Scala N, Bayer C \& Fiorin JE (2011) The primary sources of carbon loss during the crop-establishment period in a subtropical Oxisol under contrasting tillage systems. Soil \& Tillage Research, 117:163-171.

Rosamond WD (2002) Dietary fiber and prevention of cardiovascular disease. Journal of the American College Cardiology, 39:57-59.

Schwab NT, Streck NA, Uhlmann LO, Ribeiro BSMR, Becker CC \& Langner JA (2017) Temperatura base para abertura de floretes e antocrono em gladíolo. Revista Ceres, 64:557-560.

Sinclair TR, Gilbert RA, Perdomo RE, Shine Jr JM, Powell G \& Montes G (2004) Sugarcane leaf area development under field conditions in Florida, USA. Field Crops Research, 88:171-178.

Streck NA, Lago I, Samboranha FK, Gabriel LF, Schwantes AP \& Schons A (2009) Temperatura base para aparecimento de folhas e filocrono da variedade de milho BRS Missões. Ciência Rural, 39:224-227.

Streck NA, Tibola T, Lago I, Buriol GA, Heldwein AB, Schneider FM \& Zago V (2005) Estimativa do plastocrono em meloeiro (Cucumis melo L.) cultivado em estufa plástica em diferentes épocas do ano. Ciência Rural, 35:1275-1280.

Streck NA, Weiss A, Xue Q \& Stephen Baenziger P (2003) Incorporating a chronology response function into the prediction of leaf appearance rate in winter wheat. Annals of Botany, 92:181-190.

Toebe M, Lopes SJ, Storck L, Silveira TR, Milani M \& Casarotto G (2010) Estimativa de plastocrono em crambe. Ciência Rural, 40:793-799. 
Vázquez-Ovando A, Rosado-Rubio G, Chel-Guerrero L \& BetancurAncona D (2009) Physicochemical properties of a fibrous fraction from chia (Salvia hispanica L.). LWT - Food Science and Technology, 42:168-173.
Win AN, Xue Y, Chen B, Liao F, Chen F, Yin N, Mei F, Wang B, Shi X, He Y \& Chai Y (2018) Chia (Salvia hispanica) experiment at a 30Ú N site in Sichuan Basin, China. Ciência Rural, 48:1-13. 